\title{
STRATEGI HUMAS DALAM INTERNALISASI LIMA NILAI BUDAYA KERJA KEMENTERIAN AGAMA DI PTKI KALIMANTAN TIMUR
}

\author{
Badrut Tamam \\ IAIN Samarinda \\ badruttamam@iain-samarinda.ac.id \\ DOI: https://doi.org/10.35719/jieman.v2i2.31
}

\begin{abstract}
Abstrak
Lembaga pendidikan melalui hubungan masyarakat memiliki tanggungjawab secara moral untuk konsisten memenuhi kebutuhan masyarakat tentang informasi yang berkaitan dengan perencanaan, pelaksanaan dan evaluasinya. Melalui humas, lembaga pendidikan memperoleh pelayanan berupa corong publikasi untuk memenuhi kebutuhan masyarakat baik internal maupun eksternal. Penelitian bertujuan untuk mengetahui bagaimana strategi Humas dalam internalisasi lima nilai budaya kerja Kementerian Agama di Perguruan Tinggi Keagamaan Islam Kalimantan Timur. Jenis penelitian ini adalah kualitatif. Data diperoleh dengan teknik observasi, wawancara, dokumentasi. Hasil penelitian mengungkapkan Humas PTKI di Kalimantan Timur, dalam membangun strategi humas guna menginternalisasikan lima nilai budaya kerja yaitu dengan memperhatikan aspek peranan dan tugas humas yakni, expert preciber, Problem solving facilitator, communicator facilitator, technican communication. Peranan humas sebagaimana tertuang dalam teori yang dikemukakan Criss Skinner tersebut menjadi formulasi bagi praktisi humas dalam membangun strategi dan internalisasi lima nilai budaya kerja yaitu integritas, profesionalitas, inovasi, tanggungjawab dan keteladanan secara inklusif.
\end{abstract}

Kata kunci: Humas, PTKI, lima budaya kerja, Kementerian Agama

\begin{abstract}
Educational institution through public relations (PR) has a moral responsibility to consistently meet society's needs on the information relating to its planning, execution and evaluation. Through public relations,
\end{abstract}


educational institution receives services in the form of public publicity to meet both internal and external needs. The research aimed to find out how a PR strategy in the internalization of the five cultural values works of the Ministry of Religious Affairs at East Kalimantan Religious College. This type of research was qualitative. Data obtained through observation techniques, interviews, and documentations. The research suggests that PTKI's public-relations in East Kalimantan, in building a PR strategy for internalizing the five cultural values of the working culture, expert preciber, the interest-facilitator problem, communicator/com-municator, technically communication techniques. The role of public relations as brought about by the criss skinner theory has become a formulation for public-relations practitioners in building a strategy and the internalization of the five cultural values of integrity, professionality, innovation, responsibility and individuality.

Keywords: public relations, PTKI, five cultural values, Ministry of Religious Affairs

\section{Pendahuluan}

Disrupsi yang menggejala dalam peradaban manusia saat ini banyak direspon oleh berbagai kalangan dengan berbagai cara. Situasi ini menjadi titik di mana gerak manusia tidak hanya sebatas pada ruang jasmani dan materiil saja, lebih dari itu peradaban saat ini berhadapan dengan kemutakhiran, modernitas, digitalisasi dan globalisasi. Kemutakhiran informasi yang makin deras terus mewarnai progres kehidupan baik secara individu maupun kelembagaan. Dinamika dan percaturan informasi untuk mencapai tujuan dan target-target tertentu pun terjadi. Dengan dinamika penyebaran informasi yang makin mudah diakses, menyebabkan masyarakat semakin menyadari haknya terhadap berbagai fasilitas layanan kelembagaan yang dibutuhkannya.

Perguruan Tinggi Keagamaan Islam (PTKI) di bawah naungan Kementerian Agama Republik Indonesia tidak bisa berpangku tangan begitu saja menyikapi derasnya arus perubahan dan kemutakhiran serta modernitas yang ditawarkan dunia saat ini. PTKI perlu mawas dengan menginternalisasikan prinsip-prinsip manajemen public relation atau hubungan masyarakat (humas) dalam mengeksplorasi rencana strategi dan apa yang menjadi visi misi lembaga ke hadapan publik.

Humas merupakan fungsi manajemen yang membangun dan mempertahankan hubungan baik yang baik dan bermanfaat antar 
idividu anggota organisasi dan publik. ${ }^{1}$ Demi tercapainya tujuan organisasi dan posisi humas yang merupakan fungsi manajemen secara tidak langsung menuntut semua organisasi untuk menempatkan humas dalam anatomi dan stuktur organisasi. Interdependensi organisasi terhadap humas secara filosofis jika dianalogikan menurut logika seperti halnya keberadaan janin dalam rahim. Pada rahim terdapat organizational environtment yang begitu purna bagi perkembangan sebuah lembaga organisasi.

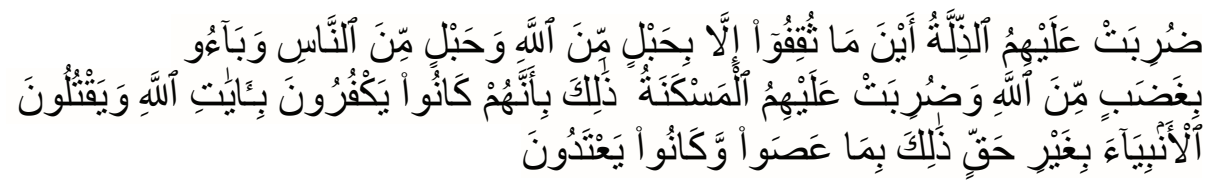

"Mereka diliputi kehinaan di mana saja mereka berada kecuali mereka berpegang kepada tali (agama) Allah dan tali (perjanjian) dengan manusia dan mereka kembali mendapat kemurkaan dari Allah dan mereka diliputi kerendahan. Yang demikian itu karena mereka kafir kepada ayat Allah dan membunuh para nabi tanpa alasan yang benar yang demikian itu disebabkan mereka durhaka dan melampaui batas. (Q.S. Ali Imron: 112)

Ayat di atas menegasikan bahwa selain menjalin hubungan yang baik dengan manusia, manusia juga diharuskan memiliki kedekatan khusus kepada tuhannya. Sebagaimana telah dibuktikan oleh ilmu pengetahuan, dalam membangun organisasi sorang pemimpin perlu memperhatikan sejak dini perihal spiritual environtment anggota organisasinya. Hal ini semata-mata apabila hubungan khusus dengan tuhan tidak dibangun maka keberadaan organisasi dihawatirkan menjadi underestimated atau bahkan menjadi cacat fungsi, insufficient dan spaceless. Ujung-ujungnya akan berakhir pada ketimpangan organisasi. Maka dalam ranah inilah fungsi manajemen berupa humas tiba waktunya untuk mengambil peran dan wake up.

Untuk menjangkau pengertian lebih mendalam tentang vitalitas humas dalam posisinya dengan ranah organisasi, maka dapatlah kita melihat lebih dalam lagi tentang suguhan konsep serta analogi ilmiah yang interdependensinya jelas dan berkaitan dengan hal di atas. Dalam memandang persepsi manajemen, humas

${ }^{1}$ Khoiruddin Muchtar dan Dedi Herdiana. "Peran dan Strategi Humas Perguruan Tinggi Islam di Kota Bandung." Anida (Aktualisasi Nuansa Ilmu Dakwah) 15.2 (2016): 338. DOI: https://doi.org/10.15575/anida.v15i2.1174 
berperan sebagai a window out of the corporation through which manajemen can monitor external change and simultaneously, a window through which society can affect corporate policy. ${ }^{2}$ Dari ungkapan tersebut teridentifikasi setidaknya humas dalam organisasi memiliki setidaknya beberapa fokus dalam proses internalisasi tujuan lembaga yakni memelihara dan mengokohkan image, memantau dan menggiring opini public dan menyampaikannya kepada manajemen organisasi, menyuguhkan advice management dalam melakukan problem solving pada proses komunikasi manajemen, menginformasikan pada khalayak public tentang policy, activity dan personality lembaga.

Selanjutnya, dalam Handbook of Public Relation oleh Chris Skinner mengatakan bahwa keberadaan humas dalam manajemen organisasi teridentifikasi pada empat hal, di antaranya: expert prescriber, problem solving facilitator, communication facilitator, dan communication technician. ${ }^{3}$ Keempat peran dominan yang dilekatkan pada humas tersebut akan membantu lembaga dalam menggiring opini. Senada dengan itu, pada studi penelitian yang dilakukan oleh IABC tentang the excellence in public relations management menuntut humas memiliki beberapa keahlian seperti halnya dapat membangun strategi dalam memecahkan masalah, mengelola respon dan isu, melaksanakan identifikasi lingkungan, menentukan reaksi public atas organisasi dan menggunakan riset public dalam evaluasi. Humas dituntut juga dapat bernegosiasi dengan aktifis media, memahami manajemen publik, memahami resolusi konflik, mempunyai kemampuan persuasi publik bahwa organisasi yang diwakilinya benar mempunyai integritas, dan mampu mendialogkan dengan public dan menggiring perilaku sebagaimana diinginkan organisasi. ${ }^{4}$

Peter F. Drucker menyebutkan bahwa humas merupakan jantung dari peredaran dan kontruksi sebuah lembaga. ia dapat menjadi mediator, translator maupun media penyambung lidah

${ }^{2}$ Yanuar Luqman, "Peran Dan Posisi Hubungan Masyarakat Sebagai Fungsi Manajemen Perguruan Tinggi Negeri Di Semarang." Interaksi: Jurnal Ilmu Komunikasi 2.1 (2013): 10. DOI: https://doi.org/10.14710/interaksi.2.1.1-10

${ }^{3}$ Chris Skinner, Gary Mersham, Rene Benecke, Handbook of public relations, 1oth ed (Oxford University Press southern Africa, t.t.).

${ }^{4}$ Luqman, "Peran dan Posisi Hubungan Masyarakat Sebagai Fungsi Manajemen Perguruan Tinggi Negeri di Semarang." 
dari berbagai kebijakan yang dimiliki suatu lembaga. Tanggung jawabnya sampai pada tanggung jawab sosial (social responsibility). ${ }^{5}$

Citra positif sebuah lembaga menjadi sangat penting guna menunjang keberlangsungan sebuah lembaga. Sebagaimana pendapat Philiph Kotler yang menyebut citra sebuah lembaga merupakan perangkat yang dapat menarik konsumen guna memiliki ide, kesan dan keyakinan terhadap suatu obyek. ${ }^{6}$ Menurutnya keyakinan kepada subuah obyek dapat dimiliki konsumen apabila terdapat proses transformasi data melalui komunikasi yang tepat, cepat dan efektif.

Realitas teks-teks peraturan pemerintah tentang kehumasan menjadi dasar pijak langkah humas dalam perannya membangun dan mengelola humas yang proposional, efektif dan efisien dalam mendukung penerapan lima budaya kerja. Sebagaimana tertuang dalam PMA Nomor 10 tahun 2010 tentang Organisasi dan Tata Kerja Kementerian Agama yang berbunyi melaksanakan perumusan dan pelaksanaan kebijakan penyusunan norma, standar, prosedur, kriteria dan bimbingan teknis serta evaluasi di bidang hubungan masyarakat. ${ }^{7}$ PMA Nomor 13 tahun 2012 tentang Organisasi dan Tata Kerja Vertikal Kementerian Agama juga menyebutkan melakukan penyiapan bahan pelaksanaan urusan pengelolaan informasi dan hubungan masyarakat. Jelas dalam teks peraturan menteri tersebut dalam rangka mendorong penyelenggaraan lembaga yang mempunyai integritas dan akuntabilitas yang baik. Dua hal ini menjadi pertaruhan bagi sebuah lembaga terlebih lagi perguruan tinggi. Salah satu indikator terpenuhinya integritas dan akuntabilitas sebuah lembaga dapat tercermin dari komunikasi yang terjalin baik internal dan eksternal.

Berlandaskan hal tersebut di atas, perguruan tinggi dalam konteks pemberdayaan sumber daya manusia memiliki peran yang sangat sentral dan signifikan. Perguruan tinggi digadang bukan hanya sebagai lembaga penyelenggara pendidikan namun lebih dari itu ia diharap dapat menjadi instrument akademis dan praktis dalam pembangunan bangsa dari keterpurukan. Integritas dan

\footnotetext{
${ }^{5}$ Peter F Drucker, Management, 2 ed. (Harper Collins e Book, 1999), 132.

${ }^{6}$ Philip T. Kotler, Principles of Marketing, 17 ed. (Pearson, t.t.), 213.

7 "Sirandang: Peraturan No. 10 Tahun 2010 Peraturan Menteri Agama
} Nomor 10 Tahun 2010 tentang Organisasi dan Tata Kerja kementerian Agama," diakses 30 November 2020, http:/itjen.kemenag.go.id/sirandang/peraturan/ 4323-10-peraturan-menteri-agama-nomor-10-tahun-2010-tentang-organisasi-dantata-kerja-kementerian-ag. 
akuntabilitas menjadi penting bila melihat bagaimana penyelenggaraan pendidikan berasal dari masyarakat itu sendiri.

Salah seorang pemikir asal Roma bernama Marcus Tulius Cicero pernah mengungkapkan bahwa kesejahteraan sebuah komunitas berawal dari karakter. ${ }^{8}$ Hal ini diperkuat dengan ungkapan seorang Arnold Toynbee bahwa moral atau karakter menjadi penentu keberlangsungan sebuah negara. ${ }^{9}$ Hal tersebut juga menjadi perhatian Kementerian Agama Republik Indonesia beberapa tahun belakangan. Kementerian Agama melalui lima nilai budaya kerja seperti berusaha mengkondisifikasi kinerjanya agar lebih berkarakter dan mampu diinternalisasikan di lembaga yang dinaunginya.

Sehingga dalam perkembangannya lima nilai budaya kerja Kementerian Agama mulai menarik dibicarakan di ruang akademik ilmiah apalagi bila dikaitkan dengan hubungannya dengan peningkatan pelayanan dan pengembangan kualitas sebuah lembaga.

Melalui lima nilai budaya kerja, Kementerian Agama berupaya untuk menjawab hal-hal yang menjadi orientasinya selama ini. Tidak hanya itu melalui nilai budaya kerja ini Kementerian Agama berusaha menjawab pertanyaan publik yang selama ini masih berstigma negatif. Sebut saja saat publik digegerkan dengan pemberitaan di berbagai media cetak maupun online nasional dengan sebutan "lembaga paling korup" diantara lembaga pemerintah lainnya. ${ }^{10}$

Dalam proses pengamatan terhadap Perguruan Tinggi Keagamaan Islam (PTKI) seperti Humas Universitas Nahdlatul Ulama (UNU) Kaltim, Ma'had Hasan Bin Ali Samarinda, Sekolah Tinggi Ilmu Syariah (STAIS) Sangatta, penulis menemukan berbagai permasalahan dalam proses lembaga memfungsikan humas dalam ranah manajemen organisasi yang dibangunnya. Salah satu hal yang cukup kentara adalah pada aspek memposisikan peran humas sebagai alat manajemen. Humas sebagai alat dan fungsi manajemen

${ }^{8}$ Badrut Tamam dan Akhmad Muadin, "Implementasi Edupreuneurship dalam Pembentukan Karakter Sekolah Unggul," Ulumuna: Jurnal Studi Keislaman 5, no. 1 (10 Juni 2019): 13-21, https://doi.org/10.36420/ju.v5i1.3521.

${ }_{9}^{9}$ Nida F.L.K, "Intervensi Teori Perkembangan moral Lawrence Kohlberg dalam Dinamika Pendidikan Karakter." Edukasia: Jurnal Penelitian Pendidikan Islam, 8.2 (2013), 275. DOI: http://dx.doi.org/10.21043/edukasia.v8i2.754

${ }^{10}$ News okezone.com, "KPK: Kementerian Agama Masih Paling Korup,” 31 Agustus 2012. 
menuntut adanya transparansi program kerja yang mempunyai sinergitas dengan kebijakan manajemen pada perguruan tinggi. Dan bukan hanya sekadar pelengkap program kerja perguruan tinggi. Penelitian ini berusaha mengungkap strategi humas dalam internalisasi lima nilai budaya kerja.

Kajian terdahulu pernah dilakukan oleh Saras Diah Musirin dan Irwansyah mengenai komunikasi interpersonal dan budaya kerja pada kinerja pegawai pada lembaga pemerintah Tahun 2019 yang menyatakan bahwa humas memiliki spesialisasi komunikasi yang fungsinya yakni menciptakan hubungan dan koneksi harmonis antara lembaga dan publiknya. Kemudian humas merupakan unit kerja yang menghimpun totalitas kelembagaan hubungan dengan stakeholder, menyebarkan informasi dalam rangka mendapatkan citra."

Berikutnya kajian terdahulu juga pernah dilakukan oleh Riris Louisa dan Yugih Setyanto yang mengulas tentang strategi public relations melalui pendekatan nilai-nilai budaya masyarakat lokal (studi kasus program CSR di PT. Pupuk Kaltim) yang menyatakan bahwa strategi pendekatan kultural mampu membawa dampak positif bagi perusahaan. Ditinjau dari segi ekonomi, perusahaan dapat membawa dampak kesejahteraan bagi masyarakat sekitar. Hubungan masyarakat dengan perusahaan terjalin dengan prinsip saling membutuhkan. Bagi perusahaan terdapat keuntungan non materi seperti dukungan masyarakat atas keberlangsungan perusahaan. Dan hal ini menjadi modal dasar berkembangnya perusahaan. $^{12}$

Dalam penelitian ini terdapat beberapa persamaan dan perbedaan yang cukup signifikan ketika menyandingkan strategi humas dengan nilai-nilai budaya kerja Kementerian Agama. persamaannya terletak pada bahwa di penelitian yang dilakukan Saras Diah Musirin dan Irwansyah memfokuskan pada komunikasi interpersonal saat menghubungkan antara konsep kehumasan dengan variabel budaya kerja. Sedang perbedaannya yakni penulis

"Saras Diah Musirin dan Irwansyah Irwansyah, "Komunikasi Interpersonal Dan Budaya Kerja Pada Kinerja Pegawai Pada Lembaga Pemerintah," Inter Komunika: Jurnal Komunikasi 4, no. 2 (31 Desember 2019): 11634, https://doi.org/10.33376/ik.v4i2.314.

${ }_{12}$ Yugih Setyanto dan Riris Loisa, "Strategi Public Relations Melalui Pendekatan Nilai-nilai Budaya Masyarakat Lokal (Studi Kasus Program CSR di PT Pupuk Kaltim)," 2012. 
memfokuskan pada strategi humas sedang penelitian terdahulu fokus pada komunikasi humas.

Diharapkan dengan penelitian ini akan memberikan kontribusi pemikiran bagi humas dan PTKI dalam pentingnya membangun strategi dalam kinerjanya lembaga pendidikan. Secara praktis penelitian ini dapat menjadi bahan informasi pendahuluan bagi peneliti lainnya mendatang tentu dengan sudut pandang berbeda.

Berangkat dari hal tersebut, maka penelitian ini berusaha mendiskripsi bagaimana Strategi Humas dalam Internalisasi Lima Nilai Budaya Kerja di PTKI Kalimantan Timur.

\section{Pembahasan}

Hasil penelitian di tiga perguruan tinggi Keagamaan Islam di Kalimantan Timur, mengungkapkan bahwa peran Humas di Perguruan Tinggi Keagamaan Islam Kaltim seperti STAIS Sangatta, UNU Kaltim dan Ma'had Hasan bin Ali Samarinda menjalankan peran humas sesuai fungsi sebagaimana mestinya dalam membangun strategi dalam internalisasi lima budaya kerja Kementerian Agama sebagaimana dapat dipaparkan melalui pembahasan di bawah ini.

\section{Strategi Humas dalam Internalisasi Nilai Integritas}

Nilai pertama adalah integritas, bermakna bahwa aparatur negara yang berada di bawah Kementerian Agama setidaknya mampu tertanam dalam dirinya agar menjaga integritas dan keselarasan antara hak dan kewajiban. ${ }^{13}$ Integritas erat kaitannya dengan konsistensi. Pada organisasi sendiri, integritas tercermin dalam perilaku disiplin, kredibel dan menepati komitmennya. Integritas juga dapat diartikan ke dalam jujur dalam tindakan. Dari pelbagai pengertian di atas dapat ditarik kesimpulan bahwa integritas bila melekat dalam organisasi maka keberlangsungan organisasi tersebut dapat terjamin. Hal ini dikarenakan saat integritas itu terjamin keberadaannya maka kemuliaan serta kepercayaan public akan terbangun dengan baik.

Humas UNU Kaltim, STAIS Sangatta, Ma'had Hasan bin Ali Samarinda menstimulus integritas lembaga dengan menerapkan

13 Ahmad Zainuri, "Strategi Penerapan Lima Nilai Budaya Kerja di Kementerian Agama Menuju Pelayan Prima” Medina-Te: Jurnal Studi Islam 12.1 (2016): 14 . 
nilai-nilai kepecayaan, kejujuran, berpikir positif dan amanah terhadap segala yang dititipkan pada anggota organisasi dalam setiap kegiatan. Dengan begitu, integritas lembaga melalui perilaku anggota organisasi dapat dikontrol dengan baik sebagaimana diinginkan lembaga.

Perilaku berupa integritas bila dikaitkan dengan prinsipprinsip perilaku organisasi selaras atas apa yang disampaikan Yulk dan Van Fleet yang menyatakan bahwa integritas merupakan standar moralitas dan etika seseorang dan tidak berkaitan dengan situasi kebetulan. Integritas mencerminkan isi hati, moral dalam berkomitmen dan akuntabilitas diri. ${ }^{14}$ Kotter mengemukakan informasi bahwa munculnya budaya dalam sebuah organisasi bisa dalam dua tingkatan yakni yang tampak dan tidak tampak. Tingkatan pertama yang tampak selalu menekankan pada perilaku kelompok yang tidak lazim namun ketidak laziman tersebut mengalami kondisifikasi karena dilakukan secara terus-menerus dan mendapat respon dari individu dalam organisasi. Kedua yang tidak tampak biasanya berawal dari kepercayaan dan persepsi yang sama sehingga tujuannya mengarah pada satu visi yang sama. ${ }^{15}$

Erat kaitannya dengan perilaku organisasi, benang merah antara perilaku dengan kepemimpinan akan sangat terasa. Terdapat konsep kepemimpinan Qurani yang ditawarkan Islam sebagaimana diungkap oleh M. Quraish Shihab bahwa kepemimpinan Qurani dimiliki oleh seorang pemimpin yang memiliki kesehatan jasmani daan kemampuan emosi yang baik dilengkapi dengan ketulusan hati dan memiliki kedekatan khusus dengan Tuhan dalam menghadapi segala rintangan dan cobaan. ${ }^{16}$ Ciri-ciri kepemimpinan qurani di STAIS, UNU dan Ma'had Hasan bin Ali sebagaimana tampak dalam nilai-nilai kepecayaan, kejujuran, berpikir positif dan amanah yang diberikan.

${ }^{14}$ David Van Fleet dan Gary Yukl, "Theory and Research on Leadership in Organizations," 1992, 147-97.

${ }^{15}$ John P. Kotter, Dan S. Cohen, The Heart of Change: Real-Life Stories of How People Change Their Organizations, 1st ed. (Harvard Business Press, t.t.), 15.

16 Siti Aimah dan Abdi Fauji Hadiono, "Refleksi terhadap Model Kepemimpinan Qur'ani," Jurnal Darussalam: Jurnal Pendidikan, Komunikasi dan Pemikiran Hukum Islam 10, no. $2 \quad(19$ April 2019): 445, https://doi.org/10.30739/darussalam.v10i2.384. 
Temuan di atas tergolong pada konsepsi dan peran humas dalam perannya sebagai expert prescriber ${ }^{17}$ dalam menginternalisasikan nilai integritas di STAIS Sangatta dan UNU Kaltim dan Ma'had Hasan bin Ali telah mengambil peran dalam membatu mencarikan solusi dalam menyelesaikan permasalahan organisasi dengan publiknya. Sebagai praktisi komunikasi humas STAIS dan UNU mampu menjadi media fasilitator penyambung dan pembawa problem solving.

\section{Strategi Humas dalam Internalisasi Nilai Profesionalitas}

Nilai ini mengandung makna bahwa setiap pekerjaan dan aktifitas individu di bawah Kemenag harus mampu bekerja secara proporsional dan professional. Nilai ini dapat ditunjukan dengan bekerja dan berperilaku secara disiplin, memiliki kompetensi diri yang kuat, tepat waktu, efisien dalam bekerja dan dengan hasil yang baik. Dalam pengertian lain bahwa professional secara individu dapat bermakna orang yang memiliki kompetensi khusus dalam melakukan sebuah pekerjaan dan memiliki komitmen untuk menyelesaikannya dengan purna.

Melalui Humas UNU, Ma'had Hasan bin Ali dan STAIS Sangatta diperoleh informasi data bahwa setiap pekerjaan yang diamanahkan lembaga atau pimpinan organisasi pada individu atau anggota organisasi selalu memperhatikan track record dan kompetensi pelaksana kegiatan. Sebagaimana dicontohkan Humas STAIS Sangatta bahwa tiap bagian dari keanggotaan humas yang dipimpinnya memiliki job description tersendiri mengikuti kompetensi dan keahlian yang dimiliki anggota. Meski demikian di Ma'had Hasan bin Ali tetap melakukan rolling pekerjaan hal ini semata-mata demi memperkaya kemampuan anggota dengan challenge tertentu. Dengan begitu, anggota organisasi dapat eksis dan berkembang dari waktu ke waktu. Sementara itu, Humas UNU, guna mengukuhkan serta memperkaya kompetensi anggotanya diberikan pelatihan khusus seperti mengikuti diklat kehumasan serta dikursuskan khusus di lembaga-lembaga pelatihan yang kredibel seperti kursus desain, magang di media seperti Koran, diklat tata naskah dan sebagainya.

Menurut De George, profesional merupakan individu dengan profesi yang dengan profesinya tersebut dilengkapi dengan

${ }^{17}$ Chris Skinner, Gary Mersham, Rene Benecke, Handbook of public relations, 1oth ed (Oxford University Press southern Africa, t.t.). 
kompetensi tertentu dan mampu menyelesaikan pekerjaan tepat waktu secara efektif dan efisien. Dengan kata lain, professional dapat dimaknai seseorang dengan praktik pekerjaan sesuai dengan tingkat keahlian tertentu. Potensi dan kompetensi professional perlu diasah agar dalam pelaksanaan pekerjaan dapat membawa dampak yang positif, maksimal dan efisien. Ciri professionalisme yang menuntut kesempurnaan hasil memiliki prasyarat berupa kesungguhan, teliti, integritas dan konsentrasi. Sedang komponen dari sikap professional secara individu dapat berupa inisiatif, motivasi, kreatif, dipercaya. Secara sosial berupa komunikasi kelompok dan kerjasama. ${ }^{18}$

Temuan di atas memiliki tendensi bahwa peran humas dalam menggiring profesionalisme dalam bekerja di STAIS Sangatta, UNU Kaltim dan Ma'had Hasan Bin Ali memfungsikan peran humas sebagai problem solving facilitator yakni peran humas sebagai fasilitator dalam proses pemecahan masalah dalam lembaga. ${ }^{19}$ Peran ini menuntut humas agar mampu memposisikan diri dan terlibat langsung dalam manajemen penyelesaian masalah. Dalam hal profesionalisme dalam tatanan pekerjaan barang tentu terdapat masalah dalam hal efisiensi waktu dan kompetensi namun pada tiga PTKI tersebut mampu bersama-sama pimpinan membuat formula khusus yakni dengan kebijakan merotasi pekerjaan, mengikutkan dalam diklat pelatihan dan sebagainya.

\section{Strategi Humas dalam Internalisasi Nilai Inovasi}

Nilai ini menuntut agar setiap kerja pegawai dilandasi dengan kinerja yang baik dan berlandaskan inovasi sehingga tidak terjebak dalam tradisi. Inovasi juga memiliki pengertian dalam praktiknya seperti mampu menyempurnakan yang sudah ada dan mengkreasinya dengan hal yang baru yang lebih baik. Inovasi biasanya bermuatan gagasan baru yang belum pernah terpikirkan oleh orang lain sebelumnya atau bisa juga gagasan baru sebagai penyempurna gagasan sebelumnya agar menghasilkan sesuatu yang lebih maksimal dan lebih dirasakan kebermanfaatannya.

18 Marwan N M Martak, "Analisis Pengaruh Profesionalisme dan Komitmen Organisasi terhadap Prestasi Kerja Melalui Kepuasan Kerja Pada Auditor Kantor Akuntan Publik di Surabaya," Jurnal Ekonomi dan Bisnis, no. 1 (2015): 15 .

19 Chris Skinner, Gary Mersham, Rene Benecke, Handbook of public relations, 1oth ed (Oxford University Press southern Africa, t.t.). 
Dalam praktik kehumasan di UNU Kaltim, STAIS Sangatta dan Ma'had Hasan bin Ali dijumpai berbagai bentuk inovasi seperti halnya dalam pelaksanaan kegiatan rapat. Agar tidak monoton dan dapat membawa dampak positif. Humas di perguruan tinggi keagamaan Islam tersebut dalam publikasi kelembagaan menerapkan inovasi berupa membuat Koran harian file pdf yang berisi tentang kegiatan lembaga yang nantinya dapat diakses public internal dan eksternal melalui media online. Inovasi lainnya yang dapat dilihat di ketiga PTKI ini yakni media online untuk menunjang pembelajaran sudah diterapkan jauh sebelum adanya pandemic Covid-19.

Dalam Undang-Undang Nomor 19 Tahun 2002 disebutkan inovasi merupakan kegiatan penelitian, pengembangan dan rekayasa yang dilakukan dengan tujuan untuk pengembangan praktis tentang nilai dan konteks ilmu pengetahuan baru ataupun cara baru unthk menerapkan ilmu pengetahuan dan proses produksinya. Sementara itu, Everet M. Rogers mengungkapkan bahwa inovasi merupakan suatu ide dan gagasan dalam praktik pekerjaan profesi yang berlandaskan hal baru baik menggunakan teknologi ataupun tidak. ${ }^{20}$

Temuan di atas menunjukan bahwa humas tidak hanya menjadi pelengkap organisasi. Humas memfungsikan diri sebagai technican communication yakni humas melaksanakan tugas pelaksana teknik komunikasi yang menyediakan layanan teknis terhadap kepentingan lembaga pada publiknya. Tidak hanya itu, teknik kegiatan berkomunikasi sebagaimana dimaksud dalam hal ini memiliki beberapa ciri yang cukup supel yakni komunikasi dua arah atau two ways traffic communication antara lembaga dengan dengan publiknya dan begitu sebaliknya. Komunikasi dua arah ini nantinya diharapkan mampu digunakan humas untuk menganalisis feedback atau efek dari suatu kebijakan lembaga. ${ }^{21}$ Dalam hal ini tiga PTKI di Kaltim tersebut telah menunjukan sinergitas bersama pimpinan dalam membentuk teknik komunikasi yang bernilai inovasi dalam bekerja baik dalam peruntukannya untuk lembaga maupun pada publik. Hal tersebut dinilai positif guna menentukan

${ }^{20}$ Ernani Hadiyati, "Kreativitas Dan Inovasi Berpengaruh Terhadap Kewirausahaan Usaha Kecil," Jurnal Manajemen Dan Kewirausahaan (Journal of Management and Entrepreneurship) 13, no. 1 (30 September 2011): 8-16, https://doi.org/10.9744/jmk.13.1.8-16.

${ }^{21}$ Chris Skinner, Gary Mersham, Rene Benecke, Handbook of public relations, 1oth ed (Oxford University Press southern Africa, t.t.). 
inovasi seperti apa yang akan digunakan dalam memenuhi kepentingan lembaga dan public kedepannya.

\section{Strategi Humas dalam Internalisasi Nilai Tanggungjawab}

Diharapkan dengan adanya nilai tanggungjawab kinerja dari pegawai dari proses perencanaan, pelaksanaan hingga evaluasi mampu dipertanggungjawabkan dengan baik dan penuh dedikasi totalitas.

Praktisi humas di berupaya membangun komunikasi antara pejabat lembaga dengan dosen dan pegawai. Bila terjadi dinamika di kalangan pegawai terutama dalam hal pelaksanaan kegiatan, maka Humas akan berusaha menjembatani dengan jalan koordinasi dengan jajaran atasannya. Tindakan ini menuntut adanya tanggungjawab atas apa yang telah direncanakan dan dilaksanakan.

Humas UNU Kaltim berperan juga dalam membangun komunikasi antara pejabat lembaga dengan dosen dan pegawai. Membangun hubungan antar pihak lembaga dengan publik eksternal itu juga merupakan program yang terus diupayakan. Humas UNU Kaltim sering mengadakan kerjasama dengan pihak luar, selain untuk mempromosikan lembaga, juga untuk mendapatkan keuntungan- keuntungan bagi kemajuan UNU hal ini bentuk dari tanggungjawab profesi.

UNU Kaltim dalam kegiatannya selalu berupaya mengelat event-event dengan pihak internal untuk membangun citra yang baik. Pihak humas juga berkreasi untuk terus berkontribusi menjembatani berbagai kebuntuan hubungan sesama internal lembaga dengan berbagai kegiatan. Dalam hubungannya dengan pihak eksternal, STAIS Sangatta juga mengadakan berbagai kegiatan yang melibatkan pihak ekternal, dan kegiatan tersebut dianggap sangat membantu dalam menaikan citra universitas sendiri. sebagai bentuk tanggungjawab bersama citra dibangun bersama sama anggota organisasi.

Sebagai upaya membangun rasa tanggungjawab dan memupuk keakraban antar pimpinan, dosen dan pegawai, Humas juga sering menjembatani dengan program-program yang kreatif dengan mengadakan berbagai pertemuan refresing ke berbagai tempat.

Temuan tersebut sejalan dengan peran humas communication facilitator yang menyebutkan bahwa humas sebagai mediator fasilitator untuk membantu manajemen dalam hal yang menjadi keinginan publik dari badan organisasi. Manajemen memerlukan suara public yang dihimpun humas dalam berbagai instrument 
guna menjalankan proses dalam mengambil kebijakan sehingga keberlangsungan manajemen terpenuhi. Dalam hal ini praktisi humas di tiga PTKI ditemukan fakta telah menjadi fasilitator yang baik dalam mengarahkan pimpinan, dosen dan pegawai untuk memiliki rasa tanggungjawab dalam membangun kebersamaan dan citra lembaga. Hal itu ditunjukan dari pemaparan dari temuan di atas.

\section{Strategi Humas dalam Internalisasi Nilai Keteladanan}

Teladan menjadi sangat penting bagi organisasi dan dengan ini diharapkan setiap individu dari dapat menjadi teladan bagi dirinya sendiri, kerabat, kolega maupun publik yang dilayaninya. Ma'had Hasan Bin Ali Samarinda termasuk instansi yang sangat peduli dan memperhatikan hubungan harmonis baik dilingkup publik internal maupun publik eksternal, public internal Ma'had Hasan Bin Ali Samarinda ini juga menyadari betul pentingnya membina hubungan baik, dengan menciptakan atmosfir kerja yang harmonis. Ma'had Hasan Bin Ali Samarinda itu sendiri, berbagai cara dilakukan untuk membuat tempat kerja yang nyaman dan nampak seperti rumah kedua, seperti kegiatan pengajian dihari Jum'at, kegiatan makan bersama yang dinilai sangat efektif dalam mempererat tali silaturahmi antar seluruh public internal, bahkan pimpinan pun tak jarang mengikuti kegiatan makan bersama, untuk menjaga hubungan yang harmonis dilingkup fakultas.

Rangkaian kegiatan ini awalnya tidak dekat atau tidak mengenal satu sama lain, kini hubungan mereka menjadi lebih intim dan akrab, ini sesuai dengan Teori Penetrasi Sosial, yang menyatakan bahwa hubungan antar dua individu atau lebih berkembang dari asalnya yang dangkal atau tidak intim, menjadi lebih personal atau lebih intim. Menurut teori ini interaksi melewati empat tahap yang dianalogikan dengan lapisan kulit bawang yakni, tahap pertama sebagai lapisan kulit pertama merupakan orientasi, tahap kedua atau lapisan kulit kedua adalah afektif dan eksploratif, tahap ketiga atau kulit ketiga pertukaran tahap afektif, dan tahap keempat atau kulit keempat pertukaran yang stabil.

UNU Kaltim juga memperhatikan semua publik internalnya mulai dari mereka yang ada diposisi atas hingga mahasiswa, bentuk perhatian UNU ini dibangun dengan asas komunikasi yang baik. Sebagai contoh di antaranya adalah dengan program pemberian beasiswa, sama seperti universitas-universitas lainnya, 
dengan adanya beasiswa ini mahasiswa yang awalnya nyaris tidak dapat melanjutkan study-nya bisa lulus dan berhasil menyabet gelar sarjana, contohnya adalah Maman Suherman. Beliau ini adalah calon alumni yang berangkat dari keluarga yang terkategorikan kurang mampu, berkat kegigihannya dalam belajar dan beasiswa serta dukungan yang diberikan pihak UNU, maka dia akan segera lulus. Dengan segala apa yang ada di UNU ini, baik dari kegiatan-kegiatan yang sudah dipaparkan diatas hingga pemberian beasiswa kepada mahasiswanya yang berprestasi atau kurang mampu, akhirnya membuat citra UNU ini menjadi baik dan dinilai positif oleh publik internalnya.

Untuk membangun keteladanan diperlukan komunikasi yang baik antara pimpinan anggota organisasi sehingga mampu terbentuk sinergitas demi keberlangsungan lembaga. Pada Jurnal of Social and Political Sciences komunikasi mendapat beberapa pengertian yang cukup komprehensif dari beberapa pakar antaranya: komunikasi berarti sebuah proses penggambaran tentang apa, dengan cara apa dan bagaimana. Komunikasi juga merupakan proses sosial atas pesan maupun lambang guna menumbuhkan pengaruh ataupun umpan balik agar berdampak pada bentuk perilaku. Ada juga pengertian lain menyebutkan bahwa komunikasi adalah proses membagikan pesan dari sumber pada penerima sebagai sebuah aktifitas dan rangkaian tahap guna memperoleh maksud yang diinginkan. ${ }^{22}$

Dengan begitu, dapat dikatakan bahwa komunikasi merupakan aktifitas dan perilaku yang tujuannya untuk menyampaikan pesan agar memperoleh dampak kebiasaan dan pengaruh (teladan). Bagi Harold Lasswell, komunikasi memiliki beberapa unsur yang saling berkaitan antara lain source (sumber), sender (pengirim), encode (penyandi), communicator (komunikator), speaker (pembicara). ${ }^{23}$ Kelima item tersebut dapat membantu komunikasi agar berjalan efektif.

Adapun fungsi komunikasi dalam buku yang ditulis Gorge Herbert Mead terdapat empat yakni sebagai 1) komunikasi sosial yang mengisyaratkan dalam membangun konsep diri, keberlangsungan, serta membangun hubungan dengan individu lainnya. 2)

${ }^{22}$ Vera, Nawiroh, Azmi, Khaerul, "Effectivity of Communication General Election Commission Tangerang City in Socialization About 'Kotak Kosong," t.t., hlm. 13, https://doi.org/10.2139/ssrn.3413675.

23 Harold D Lasswell, Dorothy Blumenstock, World revolutionary propaganda : a Chicago study (Knopf, t.t.), 155. 
komunikasi ekspresif, komunikasi ini memiliki tujuan untuk mempengaruhi orang lain dengan kandungan perasaan ataupun emosi sumber. 3) komunikasi ritual, komunikasi ini menunjukan ekspresi alamiah dari komunitas ataupun objek tertentu.

Dari beberapa fungsi komunikasi di atas maka komunikasi yang efektif akan ditentukan dengan siapa, cara dan kapan seseorang menyampaikan pesan. Melalui komunikasi yang efektif akan membantu hubungan sosial agar terjalin signifikan. Dalam Handbook of Public Relation karya Chris Skinner dapat diperoleh pengertian bahwa humas merupakan bagian penting dari fungsi manajemen yang mengandung nilai public guna mengidentifikasi kebijakan, prosedur dari organisasi maupun individu atas kepentingan orang banyak serta melakukan rencana untuk memenuhi kebutuhan informasi publik. ${ }^{24}$

Sementara itu, pengertian lain diungkap Gary Mersham. Menurutnya, humas merupakan fungsi manajemen guna mengevaluasi ruang publik memperkenalkan produk kebijakan dari organisasi dengan cara membuat perencanaan, melaksanakan program kerja guna memperoleh pengakuan dari public. Bagi Rene Benecke bahwa humas itu merupakan sebuah proses yang berkelanjutan dari usaha manajemen untuk memperoleh good will serta perspektif positif dari konsumen, pegawai, dan publik secara integral.

Dari ketiga pengertian di atas maka dapat ditarik kesimpulan bahwa humas dapat berperan sebagai communication facilitator yang baik, technican communication yang handal, expert prescriber yang mumpuni dan problem solving process facilitator dalam mewujudkan nilai-nilai keteladanan di lembaga.

Humas UNU dan Ma'had hasan bin ali dan STAIS Sangatta dalam menginternalisasikan Lima Nilai Budaya Kerja Kementerian Agama: Integritas, Profesionalitas, Inovasi, Tanggungjawab dan Keteladanan dalam kegiatan lembaga dilakukan secara inklusif.

\section{Simpulan}

Berdasarkan paparan yang telah dilakukan, dari tiga Perguruan Tinggi Keagamaan Islam di Kalimantan Timur, dapat dijelaskan bahwa pertama, dalam membangun strategi humas dalam menginternalisasikan lima nilai budaya kerja yaitu dengan memperhatikan aspek peranan dan tugas humas yakni, expert

24 Chris Skinner, Gary Mersham, Rene Benecke, Handbook of public relations, 1oth ed (Oxford University Press southern Africa, t.t.). 
preciber, Problem solving facilitator, communicator facilitator, technican communication. Peranan humas sebagaimana tertuang dalam teori yang dikemukakan Criss Skinner tersebut menjadi formulasi bagi praktisi humas dalam membangun strategi dan internalisasi lima nilai budaya kerja yaitu integritas, profesionalitas, inovasi, tanggungjawab dan keteladanan secara inklusif.

\section{Referensi}

Aimah, Siti, dan Abdi Fauji Hadiono. "Refleksi terhadap Model Kepemimpinan Qur'ani.” Jurnal Darussalam: Jurnal Pendidikan, Komunikasi dan Pemikiran Hukum Islam 10, no. $2 \quad$ (19 April 2019): 445. https://doi.org/10.30739/darussalam.v1oi2.384.

Chris Skinner, Gary Mersham, Rene Benecke. Handbook of public relations. 1oth ed. Oxford University Press southern Africa, t.t.

David Michaelson, Institute for Public Relations. A Professional and Practitioner's Guide to Public Relations Research, Measurement, and Evaluation, Second Edition. Business Expert Press, 2014.

F Drucker, Peter. Management. 2 ed. Harper Collins e Book, 1999.

F.L.K, Nida. Intervensi Teori Perkembangan moral Lawrence Kohlberg dalam Dinamika Pendidikan Karakter. Edukasia: Jurnal Penelitian Pendidikan Islam. 8.2 (2013), 271-290 DOI: http://dx.doi.org/10.21043/edukasia.v8i2.754

Hadiyati, Ernani. "Kreativitas Dan Inovasi Berpengaruh Terhadap Kewirausahaan Usaha Kecil." Jurnal Manajemen Dan Kewirausahaan (Journal of Management and Entrepreneurship) 13, no. 1 (30 September 2011): 8-16. https://doi.org/10.9744/jmk.13.1.8-16.

Harold D Lasswell, Dorothy Blumenstock. World revolutionary propaganda : a Chicago study. Knopf, t.t.

John P. Kotter, Dan S. Cohen. The Heart of Change: Real-Life Stories of How People Change Their Organizations. 1st ed. Harvard Business Press, t.t.

Kotler, Philip T. Principles of Marketing. 17 ed. Pearson, t.t.

Luqman, Yanuar. Yanuar Luqman, "Peran Dan Posisi Hubungan Masyarakat Sebagai Fungsi Manajemen Perguruan Tinggi 
Negeri Di Semarang." Interaksi: Jurnal Ilmu Komunikasi 2.1 (2013): 1-10. DOI: https://doi.org/10.14710/interaksi.2.1.1-10

Martak, Marwan N M. "Analisis Pengaruh Profesionalisme dan Komitmen Organisasi terhadap Prestasi Kerja Melalui Kepuasan Kerja pada Auditor Kantor Akuntan Publik di SURABAYA." Jurnal Ekonomi dan Bisnis, no. 1 (2015): 15.

Muchtar, Khoiruddin, and Dedi Herdiana. "Peran dan Strategi Humas Perguruan Tinggi Islam di Kota Bandung." Anida (Aktualisasi Nuansa Ilmu Dakwah) 15.2 (2016): 317-338. DOI: https://doi.org/10.15575/anida.v15i2.1174

Musirin, Saras Diah, dan Irwansyah Irwansyah. "Komunikasi Interpersonal dan Budaya Kerja pada Kinerja Pegawai pada Lembaga Pemerintah." Inter Komunika: Jurnal Komunikasi 4, no. 2 (31 Desember 2019): 116-34. https://doi.org/10.33376/ik.v4i2.314.

okezone.com, News. "KPK: Kementerian Agama Masih Paling Korup." 31 Agustus 2012.

Setyanto, Yugih, dan Riris Loisa. "Strategi Public Relations Melalui Pendekatan Nilai-nilai Budaya Masyarakat Lokal (Studi Kasus Program CSR di PT Pupuk Kaltim)," 2012.

"Sirandang :: Peraturan No. 10 Tahun 2010 Peraturan Menteri Agama Nomor 10 Tahun 2010 tentang Organisasi dan Tata Kerja kementerian Agama." Diakses 30 November 2020. http://itjen.kemenag.go.id/sirandang/peraturan/4323-10peraturan-menteri-agama-nomor-10-tahun-2010-tentangorganisasi-dan-tata-kerja-kementerian-ag.

Tamam, Badrut, dan Akhmad Muadin. "Implementasi Edupreuneurship dalam Pembentukan Karakter Sekolah Unggul." Ulumuna: Jurnal Studi Keislaman 5, no. 1 (10 Juni 2019): 13-21. https://doi.org/10.36420/ju.v5i1.3521.

Van Fleet, David, dan Gary Yukl. "Theory and Research on Leadership in Organizations," 147-97, 1992.

Vera, Nawiroh, Azmi, Khaerul. "Effectivity of Communication General Election Commission Tangerang City in Socialization About 'Kotak Kosong," t.t. https://doi.org/10.2139/ssrn.3413675.

Zainuri, Ahmad. "Strategi Penerapan Lima Nilai Budaya Kerja di Kementerian Agama Menuju Pelayan Prima."Medina-Te: Jurnal Studi Isam 12. 1(2016): 1-14. 